\title{
ANTIBIOTIC RESIDUES AND MICROBIAL CONTAMINATION IN ANIMAL-DERIVED FOODSTUFFS IN PONTIANAK CITY, INDONESIA
}

\author{
Yuli Arif Tribudi ${ }^{1)}$, Oke Anandika Lestari ${ }^{2)}$, Musa Alfius ${ }^{3)}$, Arif Hidayatullah ${ }^{3)}$ \\ 1) Animal Science Study Program, Faculty of Agriculture, Universitas Tanjungpura, Jl. Prof. Hadari Nawawi, \\ Pontianak, West Kalimantan. 78124, Indonesia \\ ${ }^{2)}$ Food Science and Technology Study Program, Faculty of Agricullture, Universitas Tanjungpura, Jl. Prof. \\ Hadari Nawawi, Pontianak, West Kalimantan. 78124, Indonesia \\ ${ }^{3)}$ Department of Food and Animal Husbandry and Health, Jl. Adi Sucipto No. 48, West Kalimantan. 78124, \\ Indonesia \\ Email: yuliariftribudi@gmail.com
}

Submitted 14 June 2020; Accepted 25 July 2020

\begin{abstract}
Nowadays, demand for foods of animal origin is not limited in terms of quantity, but also the quality, nutritional value and safety for human consumption. Animal-derived foodstuffss can contain biological and chemical hazards through a contamination process. The aim of this study was to detect antibiotic residues and microbial contaminants in animal-derived foodstuffs, i.e. chicken meat, eggs, beef and pork. Samples were collected from different traditional markets (Flamboyan, Mawar, Kemuning and Dahlia) in Pontianak city, Indonesia. Antibiotic residues in foodstuffs were detected using the bioassay method against 4 classes of antibiotics (aminoglycoside, macrolide, penicillin and tetracycline), while the tested microbial contaminants included total plate count (TPC), Escherichia coli, Coliform and Salmonella sp.. Data obtained were analyzed using descriptive statistics. The results showed that antibiotic residues were only detected in chicken products. In chicken meat, $3(60 \%)$ samples tested positive for tetracycline, while in chicken eggs, $3(60 \%)$ and $5(100 \%)$ samples tested positive for aminoglycoside and penicillin, respectively. As per the SNI 7388:2009, of the analyzed samples, $12(100 \%)$ chicken meat, $6(75 \%)$ beef and $5(100 \%)$ pork samples exceeded the limit for TPC; $5(41.67 \%)$ chicken meat and $5(100 \%)$ pork samples exceeded the limit for both coliform bacteria and E. coli; and $7(58.33 \%)$ chicken meat and $3(37.5 \%)$ beef samples were positive for Salmonella. In conclusion, considerable levels of microbial contamination were detected in chicken and beef products in Pontianak city.
\end{abstract}

Keywords: Antibiotic; microbial contaminants; animal-derived food; hygiene; sanitation 


\section{INTRODUCTION}

Food safety refers to the practices that are implemented in order to prevent contamination of food with biological, chemical and other contaminants that are capable of affecting human health. Food safety has increasingly become a global issue due to a growing public attention to high-quality foods. Food contamination is of great concerns in many countries because consumption of contaminated food can cause foodborne illness. However, the problem of food safety is complex because it includes all foods and pre-food materials along the food chain, starting from agricultural production (upstream) up to the point of consumption by humans.

Meat, eggs and milk are animalderived foodstuffs that have high nutritional values, particularly essential amino acids that are needed by human body for the growth of new cells, replacement of damaged cells and metabolic processes. Foodstuffs contaminated with biological and chemical hazards can cause widespread illness outbreaks when they are consumed by human. One of the chemical hazards exist in animal-derived foodstuffs is antibiotic residues. Antibiotic residues in food become problematic by many aspects such as bacterial resistance against antibiotic, food allergy and food poisoning.

The problems of antibiotic residues in animal-derived foods are often associated with indiscriminate and abusive use of antibiotics in animal farming. Livestock keepers use antibiotics in animal farming with the main aims of preventing infections and enhancing animal growth. However, excessive use of antibiotics can cause antibiotic residues in animal-derived foods, which in turn affect human health (Lee et al., 2017). When the animals being slaughtered the microbial pathogens that are found in animals can contaminate and damage animal tissues, which in turn affect meat quality. Animal-derived foodstuffs, especially meat, can be easily contaminated with bacterial pathogens because of its high water content $( \pm 68.75 \%)$, which is a favorable environment for microbial growth (Syarifah and Novarieta, 2015).

Animal-derived foodstuffs are excellent media for bacterial growth. Bacteria that can contaminate food of animal origin consist of two types, namely pathogenic bacteria and spoilage bacteria. Both types of bacteria can cause foodborne illness in humans. The most common bacteria that can cause foodborne illness are Coliform, Escherichia coli, Enterococci, Staphylococcus aureus, Clostridium sp., Salmonella sp., Campylobacter sp. and Listeria sp. (Law et al., 2015)

Health is one of the most valuable assets for humans. In this regard, foods that are consumed by human must be nutritious, healthy and tasty. Although animal-derived foodstuffs are highly nutritious and tasty, poor hygienic conditions during food handling can cause contamination with pathogenic microorganisms that may be harmful for the health of consumers. Moreover, food of animal origin may contain antibiotic residues as results of the abusive use of antibiotics in animal farming. Both antibiotics residues and microbial contaminants are determinants of food safety.

Therefore, the presence or absence of antibiotic residues in animal-derived foods must be reviewed to ensure food safety. This study was conducted to detect potential

\section{How to cite:}

Tribudi, Y. A., Lestari, O. A., Alfius, M., \& Hidayatullah, A. (2020). Antibiotic Residues and Microbial Contamination in Animal-Derived Foodstuffs in Pontianak City, Indonesia. Jurnal Ilmu dan Teknologi Hasil Ternak, 15 (3), 152-161 
antibiotic residues and microbial contamination in animal-derived foodstuffs in Pontianak city, West Kalimantan province, Indonesia.

\section{MATERIALS AND METHODS}

\section{Sampling procedure}

For the detection of antibiotic residues, animal derived-foodstuffs including chicken meat, egg, beef and pork samples were randomly collected using purposive sampling method. Each foodstuff consisted of 5 samples collected from 4 different traditional markets, i.e. Flamboyan (1 seller), Mawar (1 seller), Kemuning (2 sellers) and Dahlia (1 seller) located in Pontianak city, West Kalimantan, Indonesia, from July to September 2019. For the detection of microbial contamination, chicken meat ( 3 sellers in each market), beef ( 2 sellers in each market) and pork ( 2 sellers in Flamboyan and 1 seller in other markets) samples were observed.

The number of samples collected from Flamboyan market was higher than those from other markets, because Flamboyan market is a central market in Pontianak city. Approximately $300 \mathrm{~g}$ of each meat sample was collected in a sterile plastic bag and stored in a ice box. Samples were subjected to analysis within $24 \mathrm{~h}$ after sample collection. Sample analysis was conducted at the Laboratory of Microbial Pollution and the Laboratory of Antibiotic Residues of the Department of Food and Animal Husbandry and Health, West Kalimantan province, Indonesia.

\section{Detection of antibiotic residues}

Antibiotic residues in animal-derived foodstuffs were detected using the bioassay method against 4 classes of antibiotics, namely aminoglycoside (AG), macrolide (ML), penicillin (PC) and tetracycline (TC) according the Indonesian National Standard
(SNI 7424: 2008). Briefly, approximately $10 \mathrm{~g}$ sample was cut into small pieces and mixed with $20 \mathrm{ml}$ buffer solution. The solution was homogenized and centrifuged at $3000 \mathrm{rpm}$ for $10 \mathrm{~min}$. The supernatant was taken and used for the next analysis. Petri dishes containing 5 paper discs (4 from different meat samples and 1 from antibiotic solution as a standard solution) were prepared. Next, $75 \mu$ l standard solution was dripped onto paper discs in a perpendicular manner using a micro pipette.

The standard solution used were sodium penicillin $(0.01 \quad \mathrm{IU} / \mathrm{ml})$, oxytetracycline $(1.0 \mu \mathrm{g} / \mathrm{ml})$, kanamycin $(1.0 \mu \mathrm{g} / \mathrm{ml})$, tylosine $(1.0 \mu \mathrm{g} / \mathrm{ml})$ for the detection of penicillin, tetracycline, aminoglycoside and macrolide residues, respectively. The cultures were incubated at different temperatures, i.e. $30^{\circ} \mathrm{C}$ for tetracycline group, $36^{\circ} \mathrm{C}$ for macrolide and aminoglycoside groups and $55^{\circ} \mathrm{C}$ for penicillin group, for 18 to $24 \mathrm{~h}$. The antibiotic residues were determined by measuring the inhibition zones around the paper disc using a caliper. The samples were considered positive for antibiotic residues, if they gave the inhibition zone equal to or greater than $2 \mathrm{~mm}$ of the diameter of paper disc.

\section{Detection of microbial contaminants}

Microbial contaminants, i.e. total plate count (TPC), Escherichia coli, Coliform and Salmonella sp. in meat samples were detected as per method the SNI 2897:2008 regarding "Detection methods for microbial contamination in meat, eggs and milk and their processed products" (BSN, 2008).

\section{Data analysis}

The obtained data were further analyzed descriptively and compared with the threshold for microbial contamination in animal-derived foods according to the SNI 7388:2009 (Table 1). 
Table 1. Maximum limit of microbial contamination in animal-derived foods based on the Indonesian national standard (SNI: No. 7388: 2009)

\begin{tabular}{ccccc}
\hline Foodstuff & TPC & Escherichia coli & Coliform & Salmonella \\
\hline Meat (CFU/gr) & $10^{6}$ & $10^{1}$ & $10^{2}$ & Negative \\
Milk (CFU/ml) & $10^{6}$ & $<3$ & $2 \times 10^{1}$ & Negative \\
Eggs (CFU/gr) & $10^{5}$ & $10^{1}$ & $10^{2}$ & Negative \\
\hline
\end{tabular}

\section{RESULTS AND DISSCUSION}

\section{Antibiotic residues in animal-derived foodstuffs}

Antibiotics have been used extensively in animal farming for any purposes, i.e. desease prevention and growth promotion. When slaughtering the animals the livestock keepers must consider the withdrawal time of antibiotics to ensure that the animals are legal to slaughter and safe for human consumption. But in most cases the use of antibiotic in animal farming often ignores the withdrawal time, which in turn results in the presence of antibiotic residues in processed-food of animal origin. The occurrence of antibiotic residues in animalderived foodstuffs in Pontianak city is presented in Table 2.

The results showed that antibiotic residues were not detected in beef and pork samples and only detected in chickenderived foodstuffs from traditional markets in Pontianak city. Tetracycline was detected in $3(60 \%)$ out of 5 chicken meat samples. Chicken egg samples were screened to contain aminoglycoside in 3 samples $(60 \%)$ and penicillin in all tested samples (100\%). The presence of various antibiotic residues in chicken meat and eggs was also reported by previous studies (Consalesius et al., 2014; Marliana et al., 2015; Yulianti et al., 2016).

The presence of antibiotic residues in chicken meat and eggs samples might be associated with the antibiotic misuse during maintenance period of the chickens. Furthermore, in most cases the use of antibiotic often ignores the withdrawal period, which is a period between the last dose of the antibiotic and the time when the animal can be safely slaughtered and thus, processed-food of animal origin may contain antibiotic residues. A supplementation of commercial feed containing antibiotics in animals during maintenance can lead to antibiotic residues in animal-derived products (Saniwati and Agustina, 2015). Tetracycline is the most common antibiotics used in livestock farming, especially as feed additives due to having a broad-spectrum activity, readily available and relatively inexpensive (Chinchilla and Rodríguez, 2017). Hence, many livestock keepers might still use tetracycline as feed additives in animal production up to present.

Many manufacturers usually use antibiotic compound to produce feed additives. However, the Government of the Republic of Indonesia introduced a law "Number 18 Year 2009, Article 22 Paragraph 4C" concerning "Animal Husbandry and Health" that banned the use of antibiotics as feed additives in food animals. This law becomes a legal basis for the government in limiting the use of antibiotics as feed additives with the aim of reducing antibiotic residues in animalderived foods, especially chicken meat. The irresponsible misuse of antibiotics in animal production might result in antibiotic residues in animal-derived foods, which in turn can lead to undesirable outcomes for human health, such as immune system disorders, reproductive disorders, allergies, bone marrow toxicity, nephropathy and carcinogenicity (Yang et al., 2016). In addition, consumption of antibioticcontaminated foods can lead to the emergence of antibiotic resistance, which can result in antibiotic treatment failure, extended treatment duration, increased treatment-related costs and increased risk of 
death (Masrianto et al., 2019). Due to these negative effects of antibiotic residues in foods on human health, a maximum residue limit (MRL) in livestock products (meat, milk, and eggs) were introduced (SNI 016366-2000). The MRL can be the basis to determine food safety of animal-derived foods for human consumption.

Table 2. Concurrence of antibiotic residues in animal-derived foodstuffs in Pontianak city

\begin{tabular}{|c|c|c|c|c|c|}
\hline \multirow{2}{*}{ Foodstuff } & \multirow{2}{*}{$\begin{array}{l}\text { Sample } \\
\text { number }\end{array}$} & \multicolumn{4}{|c|}{ Tested compound of antibiotics } \\
\hline & & Aminoglycoside & Macrolide & Penicillin & Tetracycline \\
\hline \multirow{5}{*}{ Chicken meat } & 1 & - & - & - & + \\
\hline & 2 & - & - & - & - \\
\hline & 3 & - & - & - & + \\
\hline & 4 & - & - & - & - \\
\hline & 5 & - & - & - & + \\
\hline \multirow{5}{*}{ Beef } & 1 & - & - & - & - \\
\hline & 2 & - & - & - & - \\
\hline & 3 & - & - & - & - \\
\hline & 4 & - & - & - & - \\
\hline & 5 & - & - & - & - \\
\hline \multirow{5}{*}{ Pork } & 1 & - & - & - & - \\
\hline & 2 & - & - & - & - \\
\hline & 3 & - & - & - & - \\
\hline & 4 & - & - & - & - \\
\hline & 5 & - & - & - & - \\
\hline \multirow{5}{*}{ Chicken eggs } & 1 & + & - & + & - \\
\hline & 2 & - & - & + & - \\
\hline & 3 & + & - & + & - \\
\hline & 4 & + & - & + & - \\
\hline & 5 & - & - & + & - \\
\hline
\end{tabular}

-:not detected; +: detected

Microbial contaminants in animalderived foodstuffs

All samples collected in this study were also analyzed for microbial contaminants, including total plate count (TPC), Escherichia coli, Coliform and Salmonella sp.. The occurrence of microbial contaminants in animal-derived foodstuffs in Pontianak city is presented in Table 3.

TPC and coliform bacteria are reliable indicators of microbial contaminants in food products. As per the SNI 7388:2009, of the analyzed samples, $12(100 \%)$ chicken meat, $6(75 \%)$ beef and $5(100 \%)$ pork samples exceeded the limit for TPC $\left(10^{6} \mathrm{CFU} / \mathrm{gram}\right.$ maximum). Five ( $41.67 \%$ ) chicken meat and $5(100 \%)$ pork samples exceeded the limit for coliform bacteria $\left(10^{1} \mathrm{CFU} / \mathrm{gram}\right.$ maximum) and E. coli $\left(10^{2} \mathrm{CFU} / \mathrm{gram}\right.$ maximum). Seven $(58.33 \%)$ chicken meat and $3(37.5 \%)$ beef samples were positive for Salmonella, but none of the pork samples were positive for this bacterium.

Microbial contamination can also occur during meat handling. Based on our observation, beef and pork were transported with pick-up trucks from the slaughterhouse to the market and thus, the meat migh be easily contaminated with microorganisms. Moreover, most of the observed markets did not have meat stalls and therefore, the sellers put meat on wooden tables with a plastic base.

Flamboyan market was the only market where the sellers used porcelain to sell the meat. Bacteria from the air and the environment in the traditional markets can potentially contaminate meat. Contamination of meat with bacteria during slaughtering process can also occur through 
feces, feathers, water scalding, eviscerated water and chiller water (Goncagül et al., 2005; Stevens et al., 2006; Cortez et al. 2006; Nógrády et al., 2008).

The results of this study showed that the level of Salmonella sp. contamination in chicken meat is higher than that in beef and pork. This is in accordance with the results of the study of Minami et al. (2010) in the markets in Thailand (0\% in beef and $48 \%$ in chicken) and Dallal et al. (2010) in the markets in Iran $(20 \%$ in beef and $45 \%$ in chicken). Salmonella is a bacteria commonly found in poultry products (Hamphrey, 2006; Capita et al., 2003). Poultry are the most common sources of Salmonella infection for humans since they are intensively reared and processed on a large scale in order to provide a cheap source of meat (Corry et al., 2002). Moreover, poultry production in areas with a highdensity of animal population can lead to the spread of Salmonella between animals in a flock (Bhunia, 2008; Huong et al., 2006).

Table 3. Microbial contaminants in animal-derived foodstuffs in Pontianak city

\begin{tabular}{|c|c|c|c|c|c|}
\hline \multirow{2}{*}{ Foodstuff } & \multirow{2}{*}{$\begin{array}{l}\text { Sample } \\
\text { number }\end{array}$} & \multicolumn{4}{|c|}{ Bacterium } \\
\hline & & TPC & Coliform & E. coli & Salmonela \\
\hline \multirow{12}{*}{ Chicken meat } & 1 & $1,5 \times 10^{8}$ & - & - & + \\
\hline & 2 & $1,3 \times 10^{7}$ & - & - & - \\
\hline & 3 & $1,1 \times 10^{8}$ & - & - & + \\
\hline & 4 & $1,4 \times 10^{7}$ & - & - & + \\
\hline & 5 & $2,3 \times 10^{8}$ & - & - & + \\
\hline & 6 & $8,1 \times 10^{7}$ & - & - & + \\
\hline & 7 & $2,9 \times 10^{7}$ & $2,8 \times 10^{5}$ & $1,1 \times 10^{5}$ & - \\
\hline & 8 & $3,4 \times 10^{8}$ & $1,8 \times 10^{5}$ & $1,1 \times 10^{5}$ & + \\
\hline & 9 & $1,2 \times 10^{7}$ & $2,9 \times 10^{5}$ & $8,8 \times 10^{5}$ & - \\
\hline & 10 & $7,9 \times 10^{8}$ & $1,6 \times 10^{4}$ & $1,3 \times 10^{4}$ & - \\
\hline & 11 & $1,4 \times 10^{7}$ & $2,8 \times 10^{5}$ & $1,4 \times 10^{5}$ & - \\
\hline & 12 & $4,9 \times 10^{7}$ & - & - & + \\
\hline \multirow{8}{*}{ Beef } & 1 & $1,8 \times 10^{8}$ & - & - & + \\
\hline & 2 & $1,0 \times 10^{7}$ & - & - & - \\
\hline & 3 & $7,9 \times 10^{6}$ & - & - & - \\
\hline & 4 & $7,0 \times 10^{5}$ & $<1 \times 10^{1}$ & $<1 \times 10^{1}$ & - \\
\hline & 5 & $9,6 \times 10^{7}$ & - & - & + \\
\hline & 6 & $1,4 \times 10^{8}$ & - & - & - \\
\hline & 7 & $1,5 \times 10^{8}$ & - & - & + \\
\hline & 8 & $1,1 \times 10^{4}$ & $<1 \times 10^{1}$ & $<1 \times 10^{1}$ & - \\
\hline \multirow{5}{*}{ Pork } & 1 & $8,6 \times 10^{6}$ & $2,3 \times 10^{5}$ & $5,7 \times 10^{4}$ & - \\
\hline & 2 & $1,4 \times 10^{7}$ & $8,4 \times 10^{4}$ & $2,5 \times 10^{4}$ & - \\
\hline & 3 & $4,3 \times 10^{7}$ & $2,9 \times 10^{4}$ & $2,4 \times 10^{2}$ & - \\
\hline & 4 & $7,3 \times 10^{7}$ & $1,2 \times 10^{6}$ & $6,1 \times 10^{5}$ & - \\
\hline & 5 & $1,6 \times 10^{7}$ & $6,7 \times 10^{4}$ & $3,2 \times 10^{4}$ & - \\
\hline
\end{tabular}

-: not detected; +: detected

Escherichia coli is a reliable hygiene and sanitation indicator. The possible reasons for more number of samples contaminated with Escherichia coli in this study could be poor sanitation and food hygiene. Microbial food contamination can occur during food processing. Unhygienic food handling can result in the presence of hazardous compounds in food, which in turn affect human health (Islam et al., 2015). The reasons for the high amount of coliform bacteria in chicken meat, beef and pork samples could be attributed to improper food handling, as well as unhygienic equipments 
and environmental conditions. Based on our observations, the meat sellers in the traditional markets sold animal-derived foodstuffs in open spaces, which are sources of pollution. In addition, the use of unwashed knives and repeated washing of meat with contaminated water might have contaminated the meat.

Generally, the sellers in the traditional markets in Pontianak city sold the chicken meat on wooden tables with a plastic base. Meanwhile, they sold beef and pork by hanging carcasses or put them on a wooden table. Moreover, Pontianak city is located on the equator where the daily temperature can reach above $30^{\circ} \mathrm{C}$ with a high humidity. These conditions can support the growth of bacteria, which are generally mesophyllic. The results of this study showed that the level of microbial contamination in chicken meat was higher than that in beef and pork. This might be caused by different environmental conditions, i.e. places to sell the products, selling time and market sanitation. Chicken meat booths were close to the booths which sold fish, vegetable, tempeh and tofu, which can potentially cause a cross contamination. Meanwhile, meat and pork booths were separated from other commodities. The equipments used for cutting the carcasses might be potential sources of bacterial contamination. The meat sellers generally used a knife to cut some products, not only the meat, but also other products, which can lead to a cross contamination. Furthermore, the meat were generally put on a wooden tables without packaging and hygienic conditions (Sartika et al., 2016). Furthermore, non-hygienic conditions will thereby potentially allow flies to act as biological vectors of Salmonella sp. (Afshari et al., 2018).

The repetitive use of unhygienic equipments and selling foods in an open space can cause microbial contamination in foods (Laluraa et al., 2014). Selling foodstuffs in an open space with varying ambient temperature and relative humidity may also cause microbial contamination like coliform in the products sold. Coliform is chategorized as mesophilic bacteria that can grow best in an optimum growth temperature of $20-24^{\circ} \mathrm{C}$, but still can grow at temperatures of $10-45^{\circ} \mathrm{C}$. Mesophilic bacteria have also an optimal growth temperature range of $25-37^{\circ} \mathrm{C}$ (Cappuccino and Sherman, 2014).

Of the analyzed samples in this study, $7(31 \%)$ chicken meat and $3(31 \%)$ beef samples tested positive for Salmonella sp., while none of the pork samples tested positive for this bacterium. High rates of contamination with Salmonella sp. in chicken meat could be due to improper food handling and unhygienic facilities in the traditional markets. AlZaabi and Khan (2017) reported that the spread of Salmonella spp. during the preparation of raw poultry-based foodstuffs is extremely difficult to prevent and therefore, strict precautions, such as proper food handling and hygienic sanitation should be implemented. However, in traditional markets, many meat sellers used a dirty knife for cutting raw meat and used it again for cutting other meat, which in turn led to the spread of various microbes in meat they sold. Furthermore, the meat were usually placed on the table in open spaces and unhygienic environments, which were favorable conditions for bacterial growth. Salmonella sp. is a group of pathogenic bacteria that can cause a foodborne disease like intestinal tract infection (salmonellosis) (Dominguez et al., 2002). Salmonella sp. is a facultative intracellular pathogen due to its ability to survive and replicate within phagocytic cells and attack macrophages, dendritic cells and epithelial cells (Bhunia, 2008). Consumption of a contaminated food with Salmonella sp. can cause typhoid fever. This bacterial group is potentially zoonotic (Srigede, 2015). Therefore, Salmonella sp. is a reliable indicator of microbial contamination in food products.

Unclean and poorly managed facilities in traditional markets may cause microbial contaminants in animal-derived foodstuffs (Zhu et al., 2014). Cross-contamination is also common in food sold in traditional 
markets, particularly when a contaminated substance comes in contact with other foods (Narumi et al., 2009). Microbial contaminants in food products also come from improper storage and handling and contact with other contaminated substances. Food contaminated with bacteria upper the limit will be slimy and moldy with lower storage capacity and undesirable smells, and becomes harmful to human health when it is consumed (Lawrie, 2009). Microbial contamination can occur on farms, during transport, pre- and post-slaughtering handling and during selling meat in the markets. Improper animal care and management can cause microbial infections as well. Slaughtering activity is one the potential sources for microbial contamination. Immediately after the animals being slaughtered, the blood is still circulated through the body of an animal, so that the use of unhygienic equipments for cutting the carcass can cause microbial contaminants through the blood. Microbial contamination can also be transferred through unhygienic workers (Akbar and Anal 2014; Roccato et al., 2015)

\section{CONCLUSION}

The presence of antibiotic residues in animal-derived foodstuffs in Pontianak city, especially in eggs indicates that the use of antibiotics in chicken farming is quite high. Furthermore, a low level of hygiene in animal-derived foodstuffs, especially in chicken meat and beef were observed, as depicted by higher levels of TPC, Escherichia coli, Coliform and Salmonella sp. than the SNI 7388:2009.

\section{REFERENCES}

Akbar, A., \& Anal, A. K. (2014). Zinc oxide nanoparticles loaded active packaging, a challenge study against Salmonella typhimurium and Staphylococcus aureus in ready-to-eat poultry meat. Food Control, 38, 8895. https://doi.org/10.1016/j.foodcont.
2013.09.065

Bhunia, A. K. (2008). Foodborne Microbial Pathogens: Mechanisms and Pathogenesis. Springer.

Capita, R., Álvarez-Astorga, M., AlonsoCalleja, C., Moreno, B., \& GarcíaFernández, M. C. (2003). Occurrence of salmonellae in retail chicken carcasses and their products in Spain. International Journal of Food Microbiology, 81(2), 169-173. https:// doi.org/10.1016/S0168-1605(02)0019 $5-2$

Cappuccino, G. J., \& Sherman, N. (2014). Microbiology. In A Laboratory Manual (10th ed.). Pearson Education.

Consalesius, A. N., Annytha, I. R. D., \& Diana, A. W. (2014). Pengkajian residu tetrasiklin dalam daging ayam pedaging, ayam kampung dan ayam petelur afkir yang dijual di Kota Kupang. Jurnal Kajian Veteriner, 2(2), 175-181.

Corry, J. E. L., Allen, V. M., Hudson, W. R., Breslin, M. F., \& Davies, R. H. (2002). Sources of salmonella on broiler carcasses during transportation and processing: modes of contamination and methods of control. Journal of Applied Microbiology, 92(3), 424432. https://doi.org/10.1046/j.1365-26 72.2002.01543.x

Cortez, A. L. L., Carvalho, A. C. F. B., Ikuno, A. A., Bürger, K. P., \& Vidal-Martins, A. M. C. (2006). Identification of Salmonella spp. isolates from chicken abattoirs by multiplex-PCR. Research in Veterinary Science, 81(3), 340-344. https://doi.org/10.1016/j.rvsc.2006.03. 006

Dallal, M. M. S., Doyle, M. P., Rezadehbashi, M., Dabiri, H., Sanaei, M., Modarresi, S., Bakhtiari, R., Sharifiy, K., Taremi, M., Zali, M. R., \& Sharifi-Yazdi, M. K. (2010). Prevalence and antimicrobial resistance profiles of Salmonella serotypes, Campylobacter and Yersinia spp. isolated from retail chicken and beef, Tehran, Iran. Food Control, 
21(4), 388-392. https://doi.org/10.10 16/j.foodcont.2009.06.001

Domínguez, C., Gómez, I., \& Zumalacárregui, J. (2002). Prevalence of salmonella and campylobacter in retail chicken meat in Spain. International Journal of Food Microbiology, 72(1-2), 165-168. https: //doi.org/10.1016/S0168-1605(01)0063 8-9

Ebrahim AlZaabi, S., \& Ali Khan, M. (2017). A Study on foodborne bacterial cross-contamination during fresh chicken preparation. Arab Journal of Nutrition and Exercise (AJNE), 2(2), 128-138. https://doi. org/10.18502/ajne.v2i2.1251

Goncagül, G., Günaydin, E., \& Carli, K. T. (2005). Prevalence of Salmonella serogroups in chicken meat. Turkish Journal of Veterinary and Animal Sciences, 29(1), 103-106.

Granados-Chinchilla, F., \& Rodríguez, C. (2017). Tetracyclines in food and feedingstuffs: from regulation to analytical methods, bacterial resistance, and environmental and health implications. Journal of Analytical Methods in Chemistry, 2017, 1-24. https://doi.org/10.1155/ 2017/1315497

Humphrey, T. (2006). Public health aspects of Salmonella enteric in food production. In Salmonella Infections, Clinical, Immunological and Molecular Aspects. Cambridge University Press.

Huong, L. Q., Reinhard, F., Padungtod, P., Hanh, T. T., Kyule, M. N., Baumann, M. P. O., \& Zessin, K. H. (2006). Prevalence of salmonella in retail chicken meat in hanoi, Vietnam. Annals of the New York Academy of Sciences, 1081(1), 257-261. https:// doi.org/10.1196/annals.1373.032

Indonesia, B. N. S. A. of. (2008). Metode pengujian cemaran mikroba dalam daging, telur dan susu, serta hasil olahannya. BSN.

Islam, S., Nasrin, N., Rizwan, F., Nahar, L.,
Bhowmik, A., Esha, S. A., Talukder, K. A., Akter, M., Roy, A., \& Ahmed, M. (2015). Microbial contamination of street vended foods from a university campus in Bangladesh. Southeast Asian Journal of Tropical Medicine and Public Health, 46(3), 480-485.

Laluraa, L. F., Lohoo, H. J., \& Mewengkang, H. W. (2014). Identifikasi bakteri escherichia pada ikan selar (Selaroides sp.) bakar di beberapa resto di kota Manado. Media Teknologi Hasil Perikanan, 2(1), 1013. https://doi.org/10.35800/mthp.2.1. 2014.5359

Law, J. W.-F., Ab Mutalib, N.-S., Chan, K.G., \& Lee, L.-H. (2015). Rapid methods for the detection of foodborne bacterial pathogens: principles, applications, advantages and limitations. Frontiers in Microbiology, 5, 1-19. https://doi. org/10.3389/fmicb.2014.00770

Lawrie, R. A. (2009). Meat Science (6th ed.). Universitas Indonesia.

Lee, H.-C., Chen, C.-M., Wei, J.-T., \& Chiu, H.-Y. (2018). Analysis of veterinary drug residue monitoring results for commercial livestock products in Taiwan between 2011 and 2015. Journal of Food and Drug Analysis, 26(2), 565-571. https://doi.org/10.101 6/j.jfda.2017.06.008

Marlina A, N., Zubaidah, E., \& Sutrisno, A. (2015). Pengaruh pemberian antibiotika saat budidaya terhadap keberadaan residu pada daging dan hati ayam pedaging dari peternakan rakyat. Jurnal Ilmu-Ilmu Peternakan, 25(2), 10-19. https://doi.org/10.217 76/ub.jiip.2016.025.02.02

Masrianto, Arief, I. I., \& Taufik, E. (2019). Analisis residu antibiotik serta kualitas daging dan hati ayam broiler di Kabupaten Pidie Jaya Provinsi Aceh. Jurnal Ilmu Produksi Dan Teknologi Hasil Peternakan, 7(3), 102-110. https://doi.org/10.29244/jipt hp.7.3.102-110 
Minami, A., Chaicumpa, W., ChongsaNguan, M., Samosornsuk, S., Monden, S., Takeshi, K., Makino, S., \& Kawamoto, K. (2010). Prevalence of foodborne pathogens in open markets and supermarkets in Thailand. Food Control, 21(3), 221226. https://doi.org/10.1016/j.foodco nt.2009.05.011

Nogrady, N., Kardos, G., Bistyak, A., Turcsanyi, I., Meszaros, J., Galantai, Z., Juhasz, A., Samu, P., Kaszanyitzky, J., \& Paszti, J. (2008). Prevalence and characterization of Salmonella infantis isolates originating from different points of the broiler chicken-human food chain in Hungary. International Journal of Food Microbiology, 127(1-2), 162167. https://doi.org/10.1016/j.ijfood micro.2008.07.005

Rizky Amiruddin, R., Darniati, \& Ismail. (2017). Isolation and identification of salmonella sp in roasted chicken from restaurant in Syiah Kuala, Banda Aceh. JIMVET, 01(3), 265-274.

Roccato, A., Uyttendaele, M., Cibin, V., Barrucci, F., Cappa, V., Zavagnin, P., Longo, A., \& Ricci, A. (2015). Survival of Salmonella Typhimurium in poultry-based meat preparations during grilling, frying and baking. International Journal of Food Microbiology, 197, 1-8. https://doi.o rg/10.1016/j.ijfoodmicro.2014.12.007

Saniwanti, S., Nuraeni, N., \& Agustina, D. (2015). Studi residu antibiotik daging broiler yang beredar di pasar tradisional Kota Kendari. Jurnal Ilmu Dan Teknologi Peternakan Tropis, 2(1), 30-38. https://doi.org/10.33772 /jitro.v2i2.3799

SNI. (2000). Batas Maksimum Cemaran Mikroba dan Batas Maksimum Residu dalam Bahan Makanan Asal Hewan.

Stevens, A., Kabore, Y., Perriergrosclaude,
J., Millemann, Y., Brisabois, A., Catteau, M., Cavin, J., \& Dufour, B. (2006). Prevalence and antibioticresistance of Salmonella isolated from beef sampled from the slaughterhouse and from retailers in Dakar (Senegal). International Journal of Food Microbiology, 110(2), 178-186. https: //doi.org/10.1016/j.ijfoodmicro.2006. 04.018

Syarifah, I., \& Novarieta, E. (2015). Deteksi Salmonella sp. pada daging sapi dan ayam. In Prosiding Seminar Nasional Teknologi Peternakan Dan Veteriner, 675-680.

Yang, X., Huang, J., Wu, Q., Zhang, J., Liu, S., Guo, W., Cai, S., \& Yu, S. (2016). Prevalence, antimicrobial resistance and genetic diversity of Salmonella isolated from retail ready-to-eat foods in China. Food Control, 60, 50-56. https://doi.org/10.1016/j.foodcont.20 15.07.019

Yulianti, N. T., Ariyani, N., Nurhidayah, \& Nugraha, E. (2016). Kajian residu antibiotik golongan tetrasiklin dan penisilin dalam daging, hati, usus dan paru-paru ayam broiler di 13 provinsi di Indonesia. Buletin Pengujian Mutu Obat Hewan, 25.

Zhu, X., Zhang, R., Chu, F., He, Z., \& Li, J. (2014). A flexsim-based optimization for the operation process of cold-chain logistics distribution centre. Journal of Applied Research and Technology, 12(2), 270-278. https://doi.org/10.10 16/S1665-6423(14)72343-0

Zuhriansyah, Imam Mustofa2, H. E. N. (2019). Deteksi pencemaran bakteri salmonella sp. pada udang putih (Penaeus merguiensis) segar di pasar tradisional Kotamadya Surabaya. Jurnal Ilmiah Perikanan Dan Kelautan, 1(1), 87-91. https://doi.org/ 10.20473/jipk.v1i1.11703 